Article

\title{
The Influence of Three Years of Supplemental Nitrogen on Above- and Belowground Biomass Partitioning in a Decade-Old Miscanthus $\times$ giganteus in the Lower Silesian Voivodeship (Poland)
}

\author{
Izabela Gołąb-Bogacz ${ }^{1}$, Waldemar Helios ${ }^{2}$, Andrzej Kotecki ${ }^{2}$, Marcin Kozak ${ }^{2}$ D and \\ Anna Jama-Rodzeńska $2, *(D)$ \\ 1 Bugaj Sp. z o.o., Bugaj Zakrzewski 5, 97-512 Kodrąb, Poland; iza.golab@o2.pl \\ 2 Institute of Agroecology and Plant Production, Wroclaw University of Environmental and Life Sciences, \\ Pl. Grunwaldzki 24A, 50-363 Wrocław, Poland; waldemar.helios@upwr.edu.pl (W.H.); \\ andrzej.kotecki@upwr.edu.pl (A.K.); marcin.kozak@upwr.edu.pl (M.K.) \\ * Correspondence: anna.jama@upwr.edu.pl; Tel.: +48-713201627
}

Received: 3 July 2020; Accepted: 23 September 2020; Published: 13 October 2020

check for updates

\begin{abstract}
Because of the different opinions regarding nitrogen $(\mathrm{N})$ requirements for Miscanthus $\times$ giganteus biomass production, we conducted an experiment with a set dose of nitrogen. The objective of this study was to examine the effects of nitrogen fertilization on the biomass yield, water content, and morphological features of rhizomes and aboveground plant parts in various terms during a growing season over the course of three years (2014-2016) in Lower Silesia (Wroclaw, Poland). The nitrogen fertilization (dose $60 \mathrm{~kg} / \mathrm{ha}$ and control) significantly affected the number of shoots $(p=0.0018)$, the water concentration of rhizomes $(p=0.0004)$ and stems $(p=0.0218)$, the dry matter yield of leaves $(p=0.0000)$, and the nitrogen uptake $(p=0.0000)$. Nitrogen fertilization significantly affected the nitrogen uptake in all plant parts $(p=0.0000)$. Although low levels of nitrogen appeared to be important in maintaining the maximum growth potentials of mature Miscanthus $\times$ giganteus, the small reductions in the above- and belowground biomass production are unlikely to outweigh the environmental costs of applying nitrogen. More studies should use the protocols for the above- and belowground yield determination described in this paper in order to create site- and year-specific fertilizer regimes that are optimized for quality and yield for autumn (green) and spring (delayed) harvests.
\end{abstract}

Keywords: Miscanthus; nitrogen fertilization; rhizomes; stem; leaves

\section{Introduction}

New technologies, excessive fossil fuel combustion, and future fossil fuel depletion will contribute to permanent changes in the natural environment. One of the most pivotal environmental problems is climate change, which is caused by the anthropogenic heating of the atmosphere as a result of rising greenhouse gas concentrations [1-5]. To overcome this difficulty, we must increase the use of renewable energy sources. Renewable energy sources play an increasingly essential role in the energy policy of European countries [6]. Among all renewable energy sources, plant biomass deserves special attention. Fast growing bioenergy crops are characterized by a great potential to provide raw material for renewable energy. Miscanthus has been proposed as a biomass energy crop in Europe [7,8], and its use could increase in the near future, as it is one of the most productive plants among bioenergy crops [9-13]. Additionally, biomass combustion is regarded to be more beneficial for the environment than fossil fuel combustion [14-16]. 
The success of this bioenergy crop is also determined by its low environmental requirements-for instance, its low nitrogen and water requirements, the mechanization of its planting and harvesting, and the resistance of the plants to diseases and pests $[13,14,16,17]$. Because of its low nutrient requirements, Miscanthus can be successfully cultivated on sandy and high organic matter soils with a wide $\mathrm{pH}$ range. Additionally, it is being successfully grown in unused marginal areas and has a tolerance to various abiotic stresses, including excessive salinity, low humidity, or the presence of heavy metals $[7,18,19]$. According to Galatsidas et al. (2018) [20], the total area of marginal land that is appropriate for Miscanthus cultivation in Europe is thought to be as high as 11.11 million ha.

For the successful development of Miscanthus production, it is necessary to consider the end specific uses and precise information on the effective management of nitrogen fertilization for different soil types under various climatic and growth conditions [14,21]. Although nitrogen is the main element that determines the efficiency of biomass production, it can have negative environmental effects such as water eutrophication and increased carbon dioxide emissions [22,23].

The literature varies regarding the nitrogen requirements for Miscanthus $\times$ giganteus biomass production [14,24-27], because the nitrogen applications of Miscanthus $\times$ giganteus are characterized by variable productivity results. The $\mathrm{N}$ requirements of Miscanthus $\times$ giganteus are low compared to those of other bioenergy crops $[16,28,29]$. According to Cadoux et al. $(2011,2012)[30,31]$, these low nutrient requirements are caused by various factors, including a high nutrient use efficiency and the nutrient recycling accumulated in the rhizomes. However, there is a serious debate about the exact need for $\mathrm{N}$ fertilizer in a given crop and whether $\mathrm{N}$ fertilizer should be required at all. The translocation of nitrogen to rhizomes during the late vegetation period is a major factor in the high efficiency of nitrogen utilization [17]. There are divergent results regarding the requirements of Mischanthus $\times$ giganteus for $\mathrm{N}$ fertilization. The findings are divided on this matter; some studies have shown that the yield increases after the application of $\mathrm{N}$ fertilizer [14,25-27,32], while some state the contrary [13,33-38].

There are many European studies that provide estimates of the belowground biomass for $M$. giganteus at a single point in time [29,36-39]; however, there have been few previous studies that determined the dynamics of the rhizome yield which were not based on regular sampling through the growing season $[40,41]$.

The organ of wintering in the Mischanthus is the rhizome, an underground part that grows horizontally that is important for nutrient storage and accumulation. Most research on the yield and biometric traits of Mischanthus is concentrated on the aboveground parts of the plants [9,14,29,42]. The main aspects of experimental research are mainly focused on the environmental impact of Mischanthus, the different terms of harvesting, the different genotypes of Mischanthus, and its chemical composition during multiannual study periods. Thus far, the elemental composition and resistance to frost and salinity have been examined in the rhizomes; however, there is a lack of information on the water content in the rhizomes during the whole growing season [43-46]. A new aspect of our research is the determination of the changes in the rhizome water content during the entire vegetation period (May-December) on a 10-year-old plant.

The objective of this study was to examine the effects of nitrogen fertilization on the number, height, and diameter of leaves on a shoot, as well as the water concentration, dry mass yield, and nitrogen uptake of Miscanthus $\times$ giganteus. The growth rate of the aboveground and belowground biomass of Miscanthus $\times$ giganteus (Greef et Deu) was evaluated in the conditions of southwest Poland, with and without nitrogen fertilization. Additionally, research was undertaken to determine the influence of nitrogen fertilization on the dynamics of the water content changes in the rhizomes during the whole vegetation period. 


\section{Materials and Methods}

\subsection{Study Site and Fertilization Treatments of Miscanthus $\times$ Giganteus}

An investigation of Miscanthus $\times$ giganteus and nitrogen fertilization was conducted after 10 years of establishing crops (2014-2016) at the Experimental Station of Wroclaw University of Environmental and Life Sciences, Pawlowice (geographical location $17^{\circ} 7^{\prime} \mathrm{E}$ and $51^{\circ} 08^{\prime} \mathrm{N}$ in the Lower Silesian Voivodship, Wrocław, Poland). Pawlowice is characterized by a vegetation period (March-November) that lasts 223-230 days, with an average temperature during the growing season of $14.5^{\circ} \mathrm{C}$ and an annual rainfall ranging between 500 and $600 \mathrm{~mm}$ (around $350 \mathrm{~mm}$ during the growing season). The soil conditions were defined as alluvial soil, very light on loose sand, and sandy gravel (V grade) (soil classification used in Poland). These soils are weak with a low humus level, and are poor in organic matter. The fifth class of soil quality ( 6 classes of soil quality: I class—-the best arable land; VI-the weakest arable soil) comprises weak arable soils [47].

Plowing was carried out in 2003 at the depth of $20-25 \mathrm{~cm}$, followed by rotary harrowing before planting. Miscanthus rhizomes (10 cm long with 3-6 nodes) were planted in a row spaced $75 \mathrm{~cm}$ apart and another row spaced $48 \mathrm{~cm}$ apart (on 1 ha-27,777 rhizomes). Miscanthus $\times$ giganteus was planted in 2004. Plantation was fertilized annually from the year 2004 to 2013 at the beginning of the growing season using the following doses: $40 \mathrm{~kg} \mathrm{ha}^{-1}$ of $\mathrm{N}$ ammonium nitrate $32 \%, 17.5 \mathrm{~kg} \mathrm{ha}^{-1}$ of P $40 \%$ enriched superphosphate, and $50 \mathrm{~kg} \mathrm{ha}^{-1}$ of $\mathrm{K}$ potassium salt. The plots were separated by a distance of $1.0 \mathrm{~m}$, and all measurements (non-destructive and destructive) were taken at least $0.2 \mathrm{~m}$ from the edge of the plot in the years 2014-2016. The dimension of the plot was around $20 \mathrm{~m}^{2}$. Nitrogen treatments of 0 and $60 \mathrm{~kg} / \mathrm{ha}$ were applied in March/April during each of the 3 years (17/3/2014, 18/3/2015, 17/4/2016) after pulling out the bedding. Fertilization was annually (from 2014 to 2016) applied during the field experiment, where the following doses were used: $17.5 \mathrm{~kg} \mathrm{ha}^{-1}$ of $\mathrm{P} 40 \%$ enriched superphosphate, $50 \mathrm{~kg} \mathrm{ha}^{-1}$ of $\mathrm{K}$ potassium salt. After fertilization, the mulch was placed in its original position.

Fertilization was applied via a hand broadcast at the beginning of the vegetation period.

No significant pests and weeds were found in the Miscanthus cultivation during the experiment, so the use of herbicides was not necessary.

\subsection{Plant Growth Measurement}

Miscanthus sampling started from the 30th day of the vegetation period and every 30 days until the end of vegetation period (June, July, August, September, October, November, and December) in the years 2014-2016. At each date of sampling, a plant sample of the aboveground part of the plant and rhizomes was sampled from an area of $0.25 \mathrm{~m}^{2}$. The fresh mass of the rhizomes and the aboveground part was determined. Additionally, 10 randomly selected shoots were sampled from each replication to perform measurements on plant material — the height of the upper leaf, the diameter measured $10 \mathrm{~cm}$ from the soil surface, and the number of leaves per one stem. All the measurements (except the number of shoots) were made on 10 shoots per plot. The number of shoots was counted from a unit of $0.25 \mathrm{~m}^{2}$ from each replication. Both white and yellow rhizomes were sampled.

Terminal (from outer rows) plants from the external rows were not included in the analysis because of the so-called edge effect. After the end of the vegetation period, Miscanthus was harvested at $10-15 \mathrm{~cm}$ using a circular saw. Harvested crops were weighed and the percentage of dry matter was determined. The dry biomass weight was determined by drying samples (specific weight, $500 \mathrm{~g}$ ) to $60{ }^{\circ} \mathrm{C}$ for up to $48 \mathrm{~h}$, then drying them at $105^{\circ} \mathrm{C}$ for $4 \mathrm{~h}$. Further, the harvested crops were weighed and the fresh mass yield was determined. The dry biomass weight was determined by drying samples (specific weight, $500 \mathrm{~g}$ ) to $60^{\circ} \mathrm{C}$ for up to $48 \mathrm{~h}$, then drying them at $105^{\circ} \mathrm{C}$ for $4 \mathrm{~h}$. On this basis, the dry biomass yield per $1 \mathrm{~m}^{2}$ in a given year was calculated.

Water concentration was calculated according to the Formula (1): 
FM-fresh mass.

DM-dry mass.

\subsection{Soil and Weather Conditions}

Tables 1 and 2 summarize the soil conditions for the Miscanthus plantation in this trial. Soil samples were twice taken (April, July) during the vegetation period and after its end (November) each year. These dates were presented as annual mean values. Soil samples were taken from the experimental field at a $0-20 \mathrm{~cm}$ soil depth and were thoroughly mixed to make a representative composite soil sample. The analysis was comprised of $\mathrm{pH}$, humus, $\mathrm{C}, \mathrm{N}, \mathrm{P}, \mathrm{K}, \mathrm{S}$, and micronutrients. Analyses were performed according to the following methods: the soil reaction $(\mathrm{pH} / \mathrm{KCl}$ (potassium chloride)) was found using the potentiometric method; the total organic carbon was found using Tiurin's method [48]; the total nitrogen (classical distillation) content was found using the Kjehdal method both in soil and plant material [48]; the available forms of potassium and phosphorus were found using the Egner-Rhiem method; magnesium was found using the Schachtschabel method [49]; the total carbon content (TOC) was found via oxidimetric titration [50]; sulfur in the extract was found using the Johnson-Nishita procedure [51]; humic substances (HS) were found using the short fractionation method [52]; and the total contents of $\mathrm{Fe}, \mathrm{Mn}, \mathrm{Zn}$, and $\mathrm{Cu}$ were found using an atomic absorption spectrophotometer (ASA) after mineralization with a concentrated mixture of acids using atomic-absorbent flame spectrophotometry Varian spectra AA 200 [52].

Table 1. The content of organic matter and soil abundance in macronutrients for a depth of $0-20 \mathrm{~cm}$ in 2014-2016.

\begin{tabular}{|c|c|c|c|c|c|c|c|c|c|}
\hline Year & $\begin{array}{c}\mathrm{pH} \\
1 \mathrm{~N} \mathrm{KCl}\end{array}$ & $\begin{array}{c}\mathrm{C} \\
\mathrm{g} \mathrm{kg}^{-1}\end{array}$ & $\begin{array}{c}\text { Humus } \\
\mathrm{g} \mathrm{kg}^{-1}\end{array}$ & $\begin{array}{c}\mathrm{N} \\
\mathrm{g} \mathrm{kg}^{-1}\end{array}$ & C:N & $\begin{array}{c}P \\
\mathrm{mg} \mathrm{kg}{ }^{-1}\end{array}$ & $\begin{array}{c}\mathrm{K} \\
\mathrm{mg} \mathrm{kg}^{-1}\end{array}$ & $\begin{array}{c}\text { Mg } \\
\text { mg kg }^{-1}\end{array}$ & $\begin{array}{c}\mathrm{S} \\
\mathrm{mg} \mathrm{kg} \mathrm{kg}^{-1}\end{array}$ \\
\hline 2014 & 5.0 & 5.82 & 10.00 & 0.58 & 10.53 & 119.6 & 114.0 & 24.3 & 188.0 \\
\hline 2015 & 5.0 & 5.86 & 10.05 & 0.60 & 10.60 & 119.6 & 115.3 & 27.3 & 192.6 \\
\hline 2016 & 4.8 & 5.86 & 10.05 & 0.59 & 10.63 & 119.7 & 112.6 & 26.0 & 190.0 \\
\hline
\end{tabular}

Table 2. Soil abundance in the micronutrients at the depth of 0-20 cm in 2014-2016.

\begin{tabular}{|c|c|c|c|c|}
\hline Year & $\begin{array}{c}\text { Fe } \\
\mathrm{mg} \mathrm{kg}^{-1}\end{array}$ & $\begin{array}{c}\text { Mn } \\
\mathrm{mg} \mathrm{kg}^{-1}\end{array}$ & $\begin{array}{c}\mathrm{Zn} \\
\mathrm{mg} \mathrm{kg}^{-1}\end{array}$ & $\begin{array}{c}\mathrm{Cu} \\
\mathrm{mg} \mathrm{kg}^{-1}\end{array}$ \\
\hline 2014 & 428 & 93.4 & 82.3 & 1.82 \\
\hline 2015 & 461 & 97.1 & 79.4 & 1.69 \\
\hline 2016 & 463 & 95.2 & 78.5 & 1.78 \\
\hline
\end{tabular}

The soil's carbon stock was typical for light alluvial soils, and the C: N ratio was on average 10.6:1, which indicates the appropriate process of the organic decomposition (Table 1). In the experimental years, the soil reaction ranged from 4.8 to 5.0 (acidic), which was favorable for Miscanthus cultivation, and the arable layer's richness in nutrients was as follows: $\mathrm{P}$-very high; $\mathrm{K}$-medium; $\mathrm{Mg}$-low; $\mathrm{S}-$ medium; Fe-low; $\mathrm{Mn}$-medium; $\mathrm{Zn}$-high; and $\mathrm{Cu}$-low (Tables 1 and 2). The assessment of the soil's nutrient content was determined by limit numbers to assess the content of elements developed by the Polish Institute of Soil and Plant Cultivation in Puławy [47].

Monthly data on the temperature and precipitation in the years 2014-2016 are presented in Table 3. The temperatures in the years 2014-2016 oscillated between $\pm 9{ }^{\circ} \mathrm{C}$ in IV through to an average of $\pm 17^{\circ} \mathrm{C}$ from V to VIII. During the experimental years, the thermal conditions were favorable for the development of Miscanthus, with mild winters characterized by positive temperatures. The highest temperatures were recorded in 2015, while the lowest were in 2016 (Table 3). 
The optimal amount of rainfall for Miscanthus $\times$ giganteus depends on many factors, including the air temperature, soil type, and groundwater level; however, $600 \mathrm{~mm}$ was sufficient for the development of Miscanthus $[14,26]$. The year with the lowest rainfall was 2015. Despite the lack of rainfall, there were no reduction in the yield. The highest rainfall during the growing season was recorded in 2016 (Table 3).

Table 3. Weather conditions during 2014-2016 with a 30-year average for Wroclaw, Lower Silesia (Poland).

\begin{tabular}{ccccccccc}
\hline & \multicolumn{4}{c}{ Temperature [ $\left.{ }^{\circ} \mathbf{C}\right]$} & \multicolumn{3}{c}{ Precipitation [mm] } \\
\cline { 2 - 9 } Month & $\mathbf{2 0 1 4}$ & $\mathbf{2 0 1 5}$ & $\mathbf{2 0 1 6}$ & $\begin{array}{c}\text { Average } \\
\mathbf{1 9 8 1 - 2 0 1 0}\end{array}$ & $\mathbf{2 0 1 4}$ & $\mathbf{2 0 1 5}$ & $\mathbf{2 0 1 6}$ & $\begin{array}{c}\text { Average } \\
\mathbf{1 9 8 1 - 2 0 1 0}\end{array}$ \\
\hline I & 0.0 & 2.3 & -1.2 & -0.8 & 35.8 & 46.0 & 33.4 & 31.9 \\
II & 3.7 & 1.5 & 3.8 & 0.3 & 1.2 & 15.6 & 56.2 & 26.7 \\
III & 7.0 & 5.4 & 4.3 & 3.8 & 40.1 & 39.5 & 55.9 & 31.7 \\
IV & 10.6 & 8.9 & 8.7 & 8.9 & 55.2 & 15.8 & 46.4 & 30.5 \\
V & 13.3 & 13.5 & 15.3 & 14.4 & 101.4 & 21.0 & 5.3 & 51.3 \\
VI & 16.6 & 16.6 & 18.6 & 17.1 & 40.2 & 73.3 & 44.6 & 59.5 \\
VII & 21.2 & 20.3 & 19.5 & 19.3 & 52.9 & 55.6 & 114.3 & 78.9 \\
VIII & 17.3 & 22.7 & 17.9 & 18.3 & 75.0 & 5.6 & 27.1 & 61.7 \\
IX & 15.5 & 15.1 & 16.4 & 13.6 & 72.2 & 23.2 & 44.7 & 45.3 \\
X & 10.7 & 8.4 & 8.5 & 9.1 & 59.4 & 20.0 & 83.8 & 32.3 \\
XI & 6.6 & 6.2 & 3.4 & 3.9 & 15.5 & 52.4 & 36.3 & 36.6 \\
XII & 2.3 & 5.4 & 1.2 & 0.2 & 17.5 & 24.0 & 36.1 & 37.4 \\
Average annual air & & & & & & & & \\
temperature and & 10.4 & 10.5 & 9.7 & 9.0 & 566.4 & 392.0 & 584.1 & 523.8 \\
total precipitation & & & & & & & & \\
\hline
\end{tabular}

\subsection{Statistical Analysis}

The experiment was conducted with a randomized block design in four replications to test the effects of $\mathrm{N}$ fertilization on the morphological traits and yield of Mischanthus. The analysis of variance (ANOVA) and the mixed model with repeated measurements was used. The doses of nitrogen fertilizers were assumed to be a fixed factor, while the years were random. The results of the biometric measurements of the Mischanthus were analyzed via ANOVA in the Statistica program (13.1 StatSoft, Kraków, Poland).

\section{Results}

\subsection{Effect of Nitrogen Fertilization on Morphological Features of Miscanthus $\times$ Giganteus}

Nitrogen fertilization had a significant influence on the number of leaves on the shoot $(p=0.0018)$ during the field experiment (Table 4). Both the number of shoots and the height of the plants increased significantly until the end of vegetation period (Figures 1 and 2). Without $\mathrm{N}$ fertilization, the shoots reached $3.34 \mathrm{~m}$ in height, whereas the height of plants after an application of $60 \mathrm{~kg} \mathrm{ha}^{-1} \mathrm{~N}$ was $3.31 \mathrm{~m}$. The highest increases in height of shoots on unfertilized plots were found between June and July, while in fertilized plants they was found between July and August. The greatest increase in shoot diameter was found at the beginning of the vegetation period (Figure 3). A fast increase in the number of leaves on the shoot was observed in September. Between September and November, the differences were insignificant (Figure 4). The number of leaves on both fertilized and unfertilized shoots increased until November. After this period, it decreased. 
Table 4. Morphological features of Miscanthus $\times$ giganteus (average for years 2014-2016).

\begin{tabular}{|c|c|c|c|c|c|}
\hline $\begin{array}{c}\text { Dose } \\
\mathrm{kg} \mathrm{ha}^{-1} \mathrm{~N}\end{array}$ & $\begin{array}{c}\text { Number of Days Starting } \\
\text { from Beginning of } \\
\text { Vegetation Period }\end{array}$ & $\begin{array}{l}\text { Number of } \\
\text { Shoots } \\
\text { per } 1 \mathrm{~m}^{2}\end{array}$ & $\begin{array}{l}\text { Height of } \\
\text { Plants } \\
\text { (m) }\end{array}$ & $\begin{array}{l}\text { Diameter } \\
\text { of Shoots } \\
(\mathrm{mm})\end{array}$ & $\begin{array}{c}\text { Number of } \\
\text { Leaves on } \\
\text { Shoot }\end{array}$ \\
\hline \multirow{7}{*}{0} & June & 52 & 0.18 & 8.5 & 3.1 \\
\hline & July & 59 & 1.23 & 10.3 & 5.9 \\
\hline & August & 64 & 2.14 & 9.7 & 8.7 \\
\hline & September & 64 & 2.33 & 10.5 & 10.7 \\
\hline & October & 66 & 2.98 & 9.6 & 11.3 \\
\hline & November & 74 & 3.07 & 10.0 & 11.7 \\
\hline & December & 72 & 3.34 & 10.8 & 8.9 \\
\hline \multirow{7}{*}{60} & June & 53 & 0.21 & 9.1 & 3.8 \\
\hline & July & 64 & 1.04 & 9.9 & 5.9 \\
\hline & August & 66 & 2.24 & 10.1 & 8.8 \\
\hline & September & 76 & 2.71 & 10.8 & 11.3 \\
\hline & October & 78 & 3.09 & 10.2 & 12.1 \\
\hline & November & 72 & 3.13 & 10.5 & 12.4 \\
\hline & December & 78 & 3.31 & 10.8 & 11.2 \\
\hline & $p$ value & 0.2884 & 0.0001 & 0.4553 & 0.0322 \\
\hline \multicolumn{6}{|c|}{ Averages for Factors and Years } \\
\hline 0 & - & 64 & 2.18 & 9.9 & 8.6 \\
\hline 60 & - & 70 & 2.25 & 10.2 & 9.3 \\
\hline & $p$ value & 0.0018 & 0.7020 & 0.1004 & 0.1484 \\
\hline 2014 & \multirow{3}{*}{-} & 67 & 2.28 & 10.0 & 8.5 \\
\hline 2015 & & 66 & 2.20 & 10.0 & 8.6 \\
\hline 2016 & & 68 & 2.16 & 10.2 & 9.9 \\
\hline & $p$ value & 0.4112 & 0.8354 & 0.4200 & 0.4040 \\
\hline
\end{tabular}

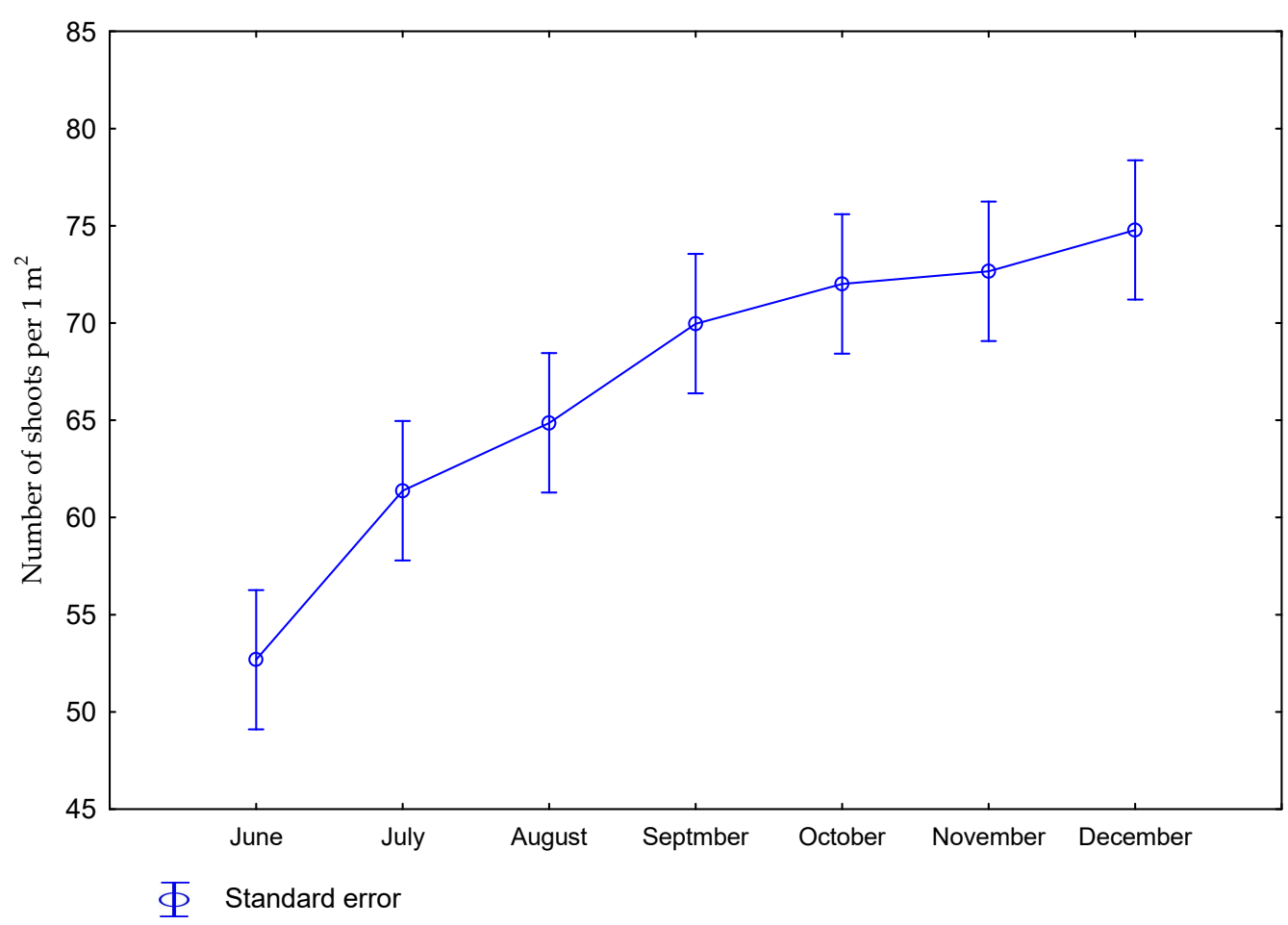

Figure 1. The number of shoots during the vegetation period in the years 2014-2016 (average for years). 


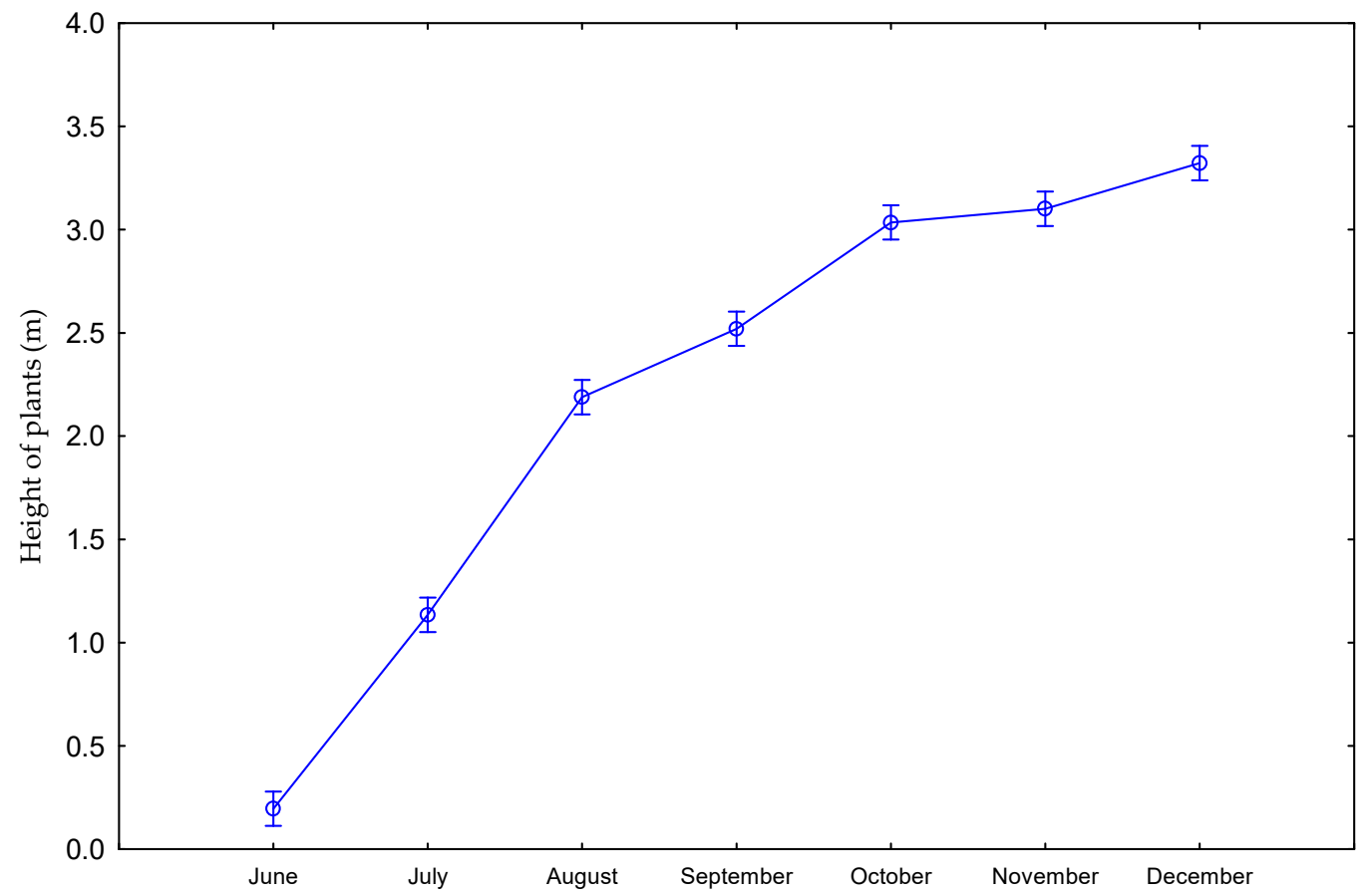

Figure 2. The height of plants during the vegetation period in the years 2014-2016 (average for years).

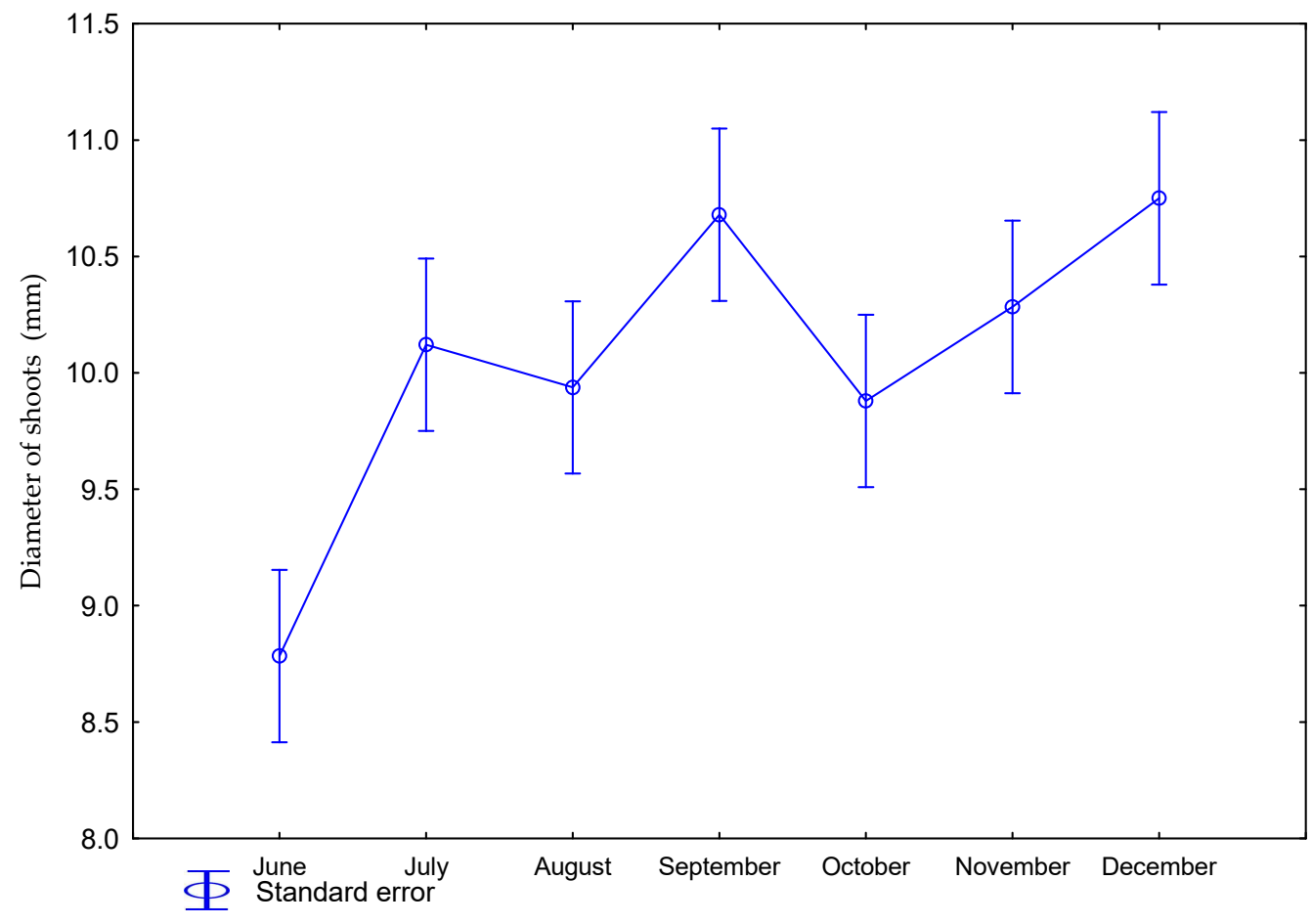

Figure 3. Diameter of shoots during the vegetation period in the years 2014-2016 (average for years). 


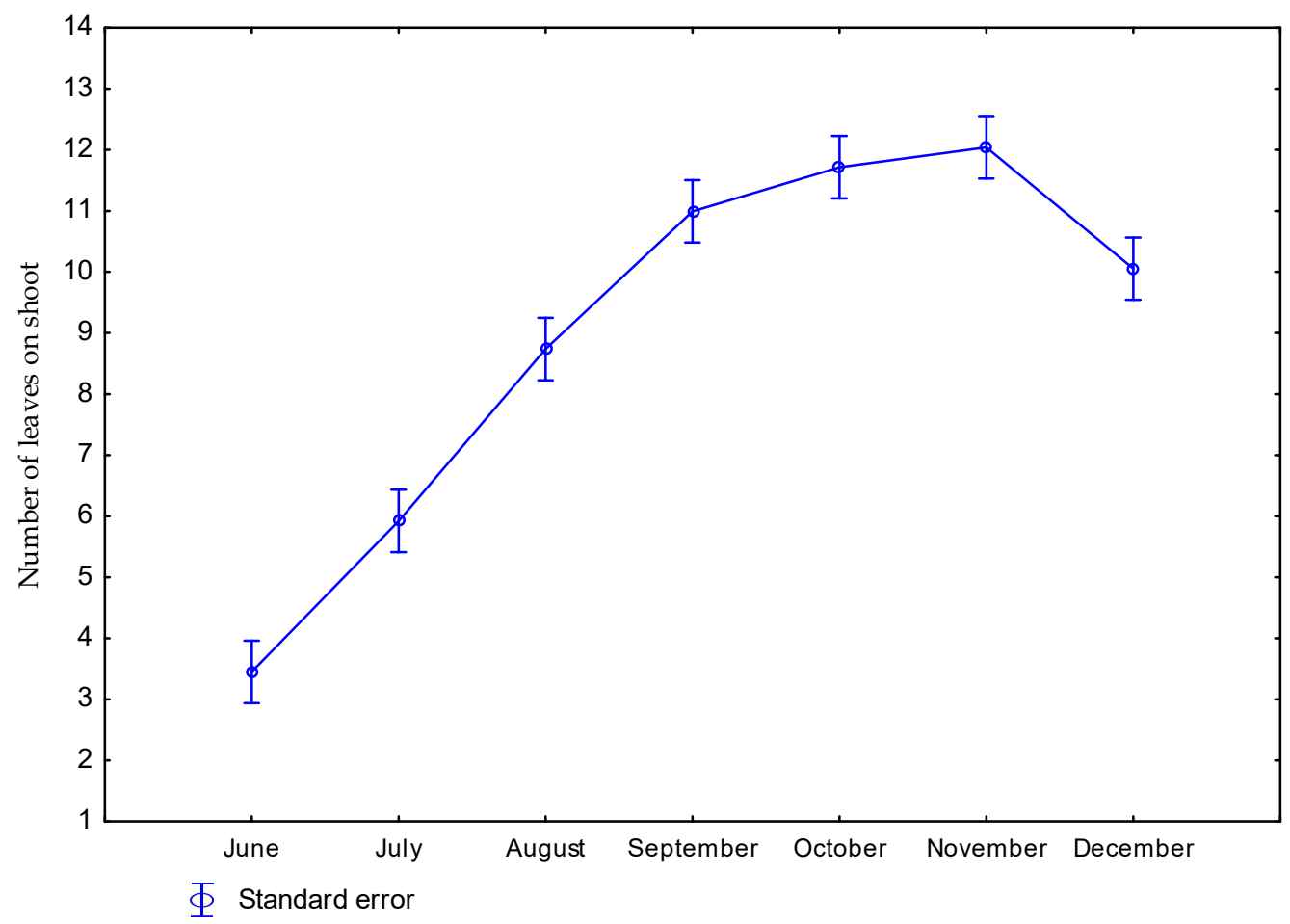

Figure 4. Number of leaves on the shoots during the vegetation period in the years 2014-2016 (average for years).

\subsection{Effect of Nitrogen Fertilization on Water Concentration of Miscanthus $\times$ Giganteus}

The water concentration was characterized with differences between the examined parts of plants. The rhizomes, stems, and leaves were characterized by a higher water concentration at the beginning of the growing season (Table 5, Figures 5 and 6). On fertilized and unfertilized plots, the water content in the leaves $(p=0.0260)$ and stems $(p=0.0015)$ decreased until the end of the vegetation period. For rhizomes, the water content decreased until October and then increased at about $7 \mathrm{~g}$ in the unfertilized plot and $31 \mathrm{~g}$ in the fertilized plot. There was a significantly higher water concentration found in the rhizomes $(p=0.004)$ and stems $(p=0.0218)$ fertilized with nitrogen. The water concentration was significantly different during the experimental years. The highest content of water was observed in the rhizomes $(p=0.0000)$, stems $(p=0.0022)$, leaves $(p=0.0000)$, and whole aboveground parts of plants $(p=0.0025)$ in the third year of the study (Table 5). A greater water content in the aboveground part of plants was observed until November (Figure 6).

Table 5. Water concentration in the fresh mass of Miscanthus $\times$ giganteus $\left(\mathrm{g} \mathrm{kg}^{-1}\right)$ (average for years 2014-2016).

\begin{tabular}{cccccc}
\hline $\begin{array}{c}\text { Dose } \\
\mathbf{k g ~ h a} \mathbf{~}^{\mathbf{1}} \mathbf{N}\end{array}$ & $\begin{array}{c}\text { Number of Days Starting } \\
\text { from Beginning of } \\
\text { Vegetation Period }\end{array}$ & Rhizomes & Stems & Leaves & $\begin{array}{c}\text { Aboveground } \\
\text { Part of Plant }\end{array}$ \\
\hline & June & 722 & - & - & 882 \\
July & 689 & 870 & 879 & 875 \\
0 & August & 709 & 772 & 777 & 775 \\
& September & 684 & 697 & 715 & 702 \\
& October & 663 & 691 & 702 & 694 \\
November & 663 & 662 & 698 & 672 \\
December & 670 & 622 & 679 & 635 \\
\hline
\end{tabular}


Table 5. Cont.

\begin{tabular}{|c|c|c|c|c|c|}
\hline $\begin{array}{c}\text { Dose } \\
\mathrm{kg} \mathrm{ha}^{-1} \mathrm{~N}\end{array}$ & $\begin{array}{c}\text { Number of Days Starting } \\
\text { from Beginning of } \\
\text { Vegetation Period }\end{array}$ & Rhizomes & Stems & Leaves & $\begin{array}{l}\text { Aboveground } \\
\text { Part of Plant }\end{array}$ \\
\hline \multirow{7}{*}{60} & June & 744 & - & - & 883 \\
\hline & July & 707 & 867 & 853 & 862 \\
\hline & August & 712 & 827 & 810 & 820 \\
\hline & September & 713 & 764 & 781 & 769 \\
\hline & October & 673 & 720 & 740 & 726 \\
\hline & November & 683 & 676 & 707 & 685 \\
\hline & December & 704 & 661 & 701 & 672 \\
\hline & $p$ value & 0.4958 & 0.0015 & 0.0260 & 0.00120 \\
\hline \multicolumn{6}{|c|}{ Average for Factors and Years } \\
\hline 0 & & 686 & 719 & 742 & 748 \\
\hline 60 & & 705 & 752 & 765 & 774 \\
\hline & $p$ value & 0.0004 & 0.0218 & 0.0669 & 0.0693 \\
\hline 2014 & & 673 & 714 & 722 & 738 \\
\hline 2015 & & 693 & 722 & 735 & 750 \\
\hline \multirow[t]{2}{*}{2016} & & 721 & 771 & 803 & 795 \\
\hline & $p$ value & 0.0000 & 0.0022 & 0.0000 & 0.0025 \\
\hline
\end{tabular}

$\left[\mathrm{kg}^{-1}\right]$

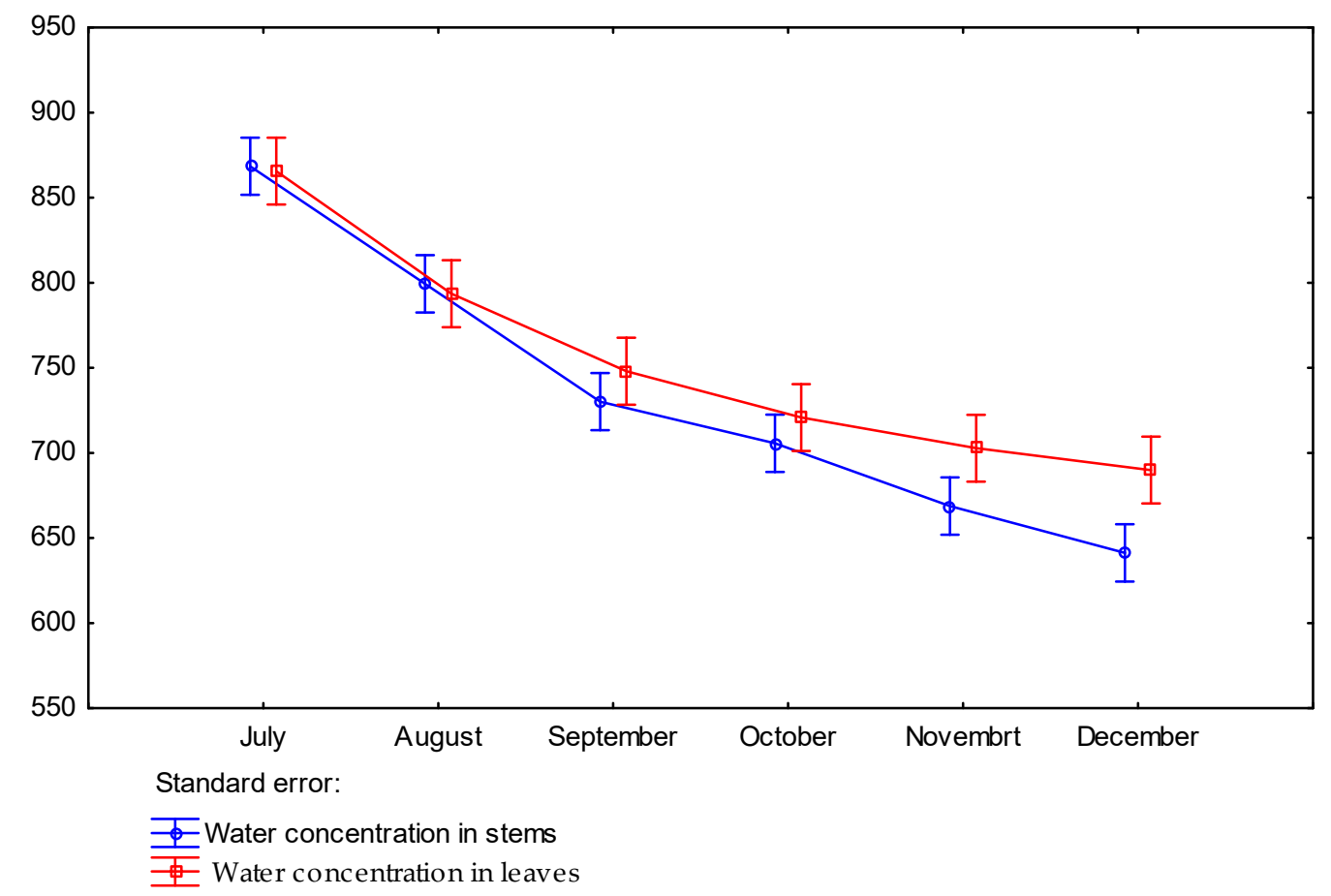

Figure 5. Water concentration in leaves and stems during the vegetation period of the years 2014-2016 (average for years). 


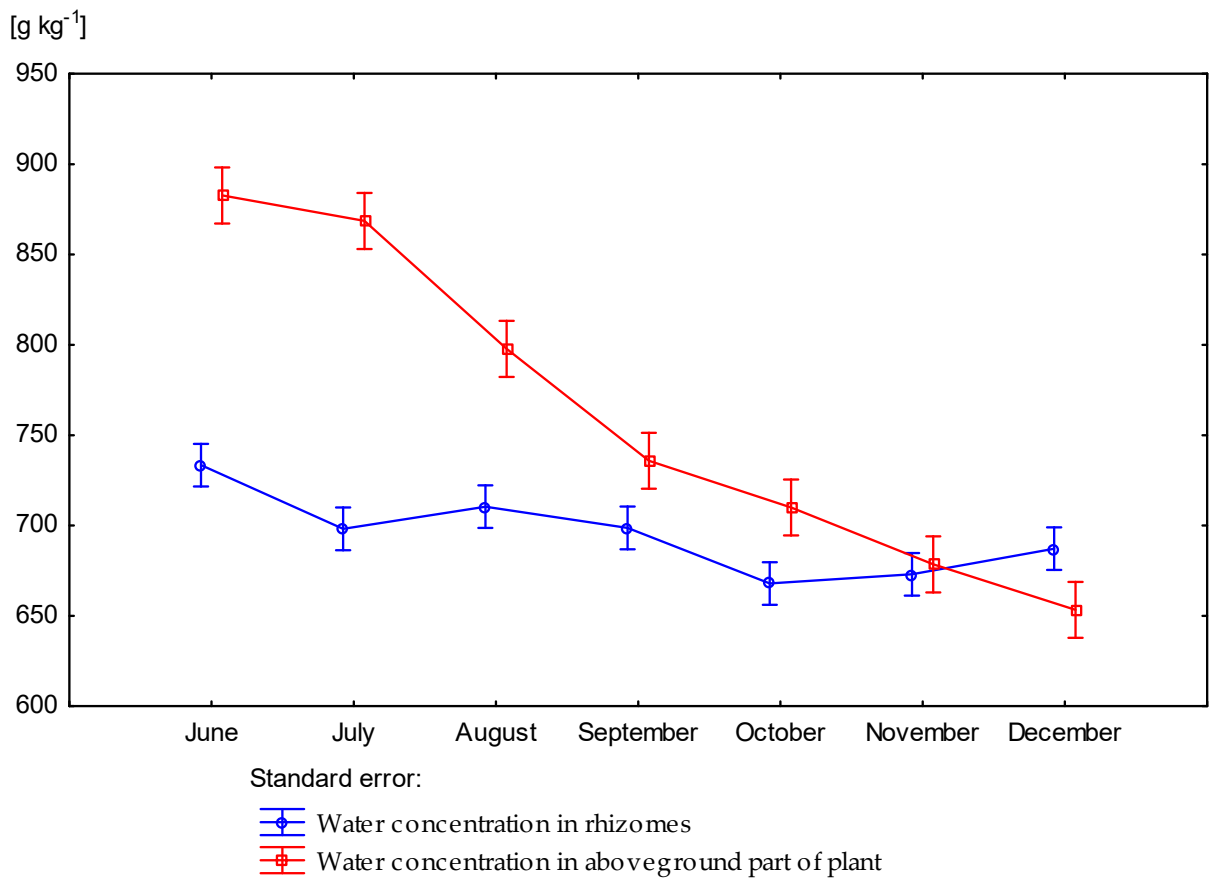

Figure 6. Water concentration in the rhizomes and aboveground part of plants during the vegetation period of the years 2014-2016 (average for years).

\subsection{Effect of Nitrogen Fertilization on Dry Matter Yield of Miscanthus $\times$ Giganteus}

Nitrogen fertilization significantly contributed to an increase in the dry matter yield of leaves $(p=0.0000)$. The nitrogen fertilization and lack of fertilization of biomass sampling was characterized by an increasing tendency in the dry mass of rhizomes and aboveground parts of plants. The dry mass of the stems grew faster than that of the leaves over the whole vegetation period (Figure 7). The highest yield growth dynamics of the whole plant was observed between August and September (Table 6, Figure 8).

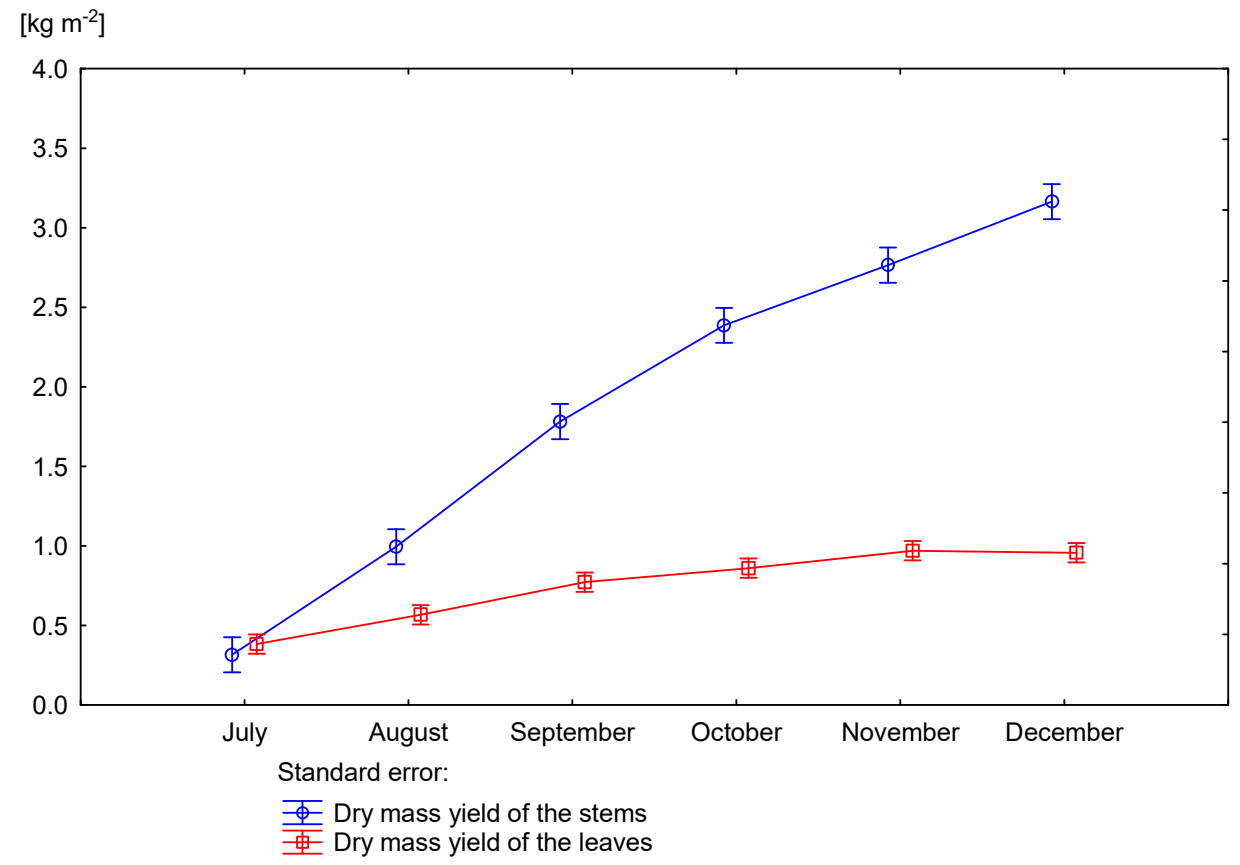

Figure 7. Dry mass yield of the leaves and stems during the vegetation period in the years 2014-2016 (average for years). 
Table 6. The yield of the dry mass of Miscanthus $\times$ giganteus $\left(\mathrm{kg} \mathrm{m}^{-2}\right)$ (average for years 2014-2016).

\begin{tabular}{|c|c|c|c|c|c|c|}
\hline \multirow{2}{*}{$\begin{array}{c}\text { Dose } \\
\mathrm{kg} \mathrm{ha}^{-1} \mathrm{~N}\end{array}$} & \multirow{2}{*}{$\begin{array}{c}\text { Number of Days Starting } \\
\text { from Beginning of Vegetation } \\
\text { Period }\end{array}$} & \multirow{2}{*}{ Rhizomes } & \multicolumn{3}{|c|}{ Aboveground Part } & \multirow{2}{*}{$\begin{array}{c}\text { Rhizomes and } \\
\text { Aboveground Part }\end{array}$} \\
\hline & & & Stems & Leaves & All Together & \\
\hline \multirow{7}{*}{0} & June & 0.52 & - & - & 0.34 & 0.86 \\
\hline & July & 0.65 & 0.28 & 0.32 & 0.60 & 1.25 \\
\hline & August & 0.77 & 0.94 & 0.45 & 1.39 & 2.16 \\
\hline & September & 1.15 & 1.67 & 0.63 & 2.30 & 3.45 \\
\hline & October & 1.34 & 2.22 & 0.78 & 3.00 & 4.34 \\
\hline & November & 1.67 & 2.81 & 0.89 & 3.70 & 5.37 \\
\hline & December & 1.73 & 3.08 & 0.84 & 3.92 & 5.65 \\
\hline \multirow{7}{*}{60} & June & 0.73 & - & - & 0.44 & 1.17 \\
\hline & July & 0.77 & 0.35 & 0.45 & 0.80 & 1.57 \\
\hline & August & 0.97 & 1.06 & 0.68 & 1.74 & 2.71 \\
\hline & September & 1.22 & 1.90 & 0.92 & 2.82 & 4.04 \\
\hline & October & 1.64 & 2.55 & 0.94 & 3.49 & 5.13 \\
\hline & November & 1.64 & 2.72 & 1.06 & 3.78 & 5.42 \\
\hline & December & 1.83 & 3.25 & 1.07 & 4.32 & 6.15 \\
\hline \multicolumn{2}{|r|}{$p$ value } & 0.0125 & 0.1223 & 0.1393 & 0.0153 & 0.0056 \\
\hline \multicolumn{7}{|c|}{ Average for Factors and Years } \\
\hline 0 & & 1.12 & 1.83 & 0.65 & 2.18 & 3.29 \\
\hline 60 & & 1.26 & 1.97 & 0.85 & 2.48 & 3.74 \\
\hline \multicolumn{2}{|r|}{$p$ value } & 0.0524 & 0.4310 & 0.0000 & 0.1586 & 0.1181 \\
\hline 2014 & & 1.20 & 2.00 & 0.75 & 2.41 & 3.61 \\
\hline 2015 & & 1.15 & 1.91 & 0.71 & 2.30 & 3.45 \\
\hline \multirow[t]{2}{*}{2016} & & 1.21 & 1.79 & 0.79 & 2.27 & 3.48 \\
\hline & $p$ value & 0.7318 & 0.6005 & 0.3165 & 0.8522 & 0.8881 \\
\hline
\end{tabular}

$\left[\mathrm{kg} \mathrm{m}^{-2}\right]$

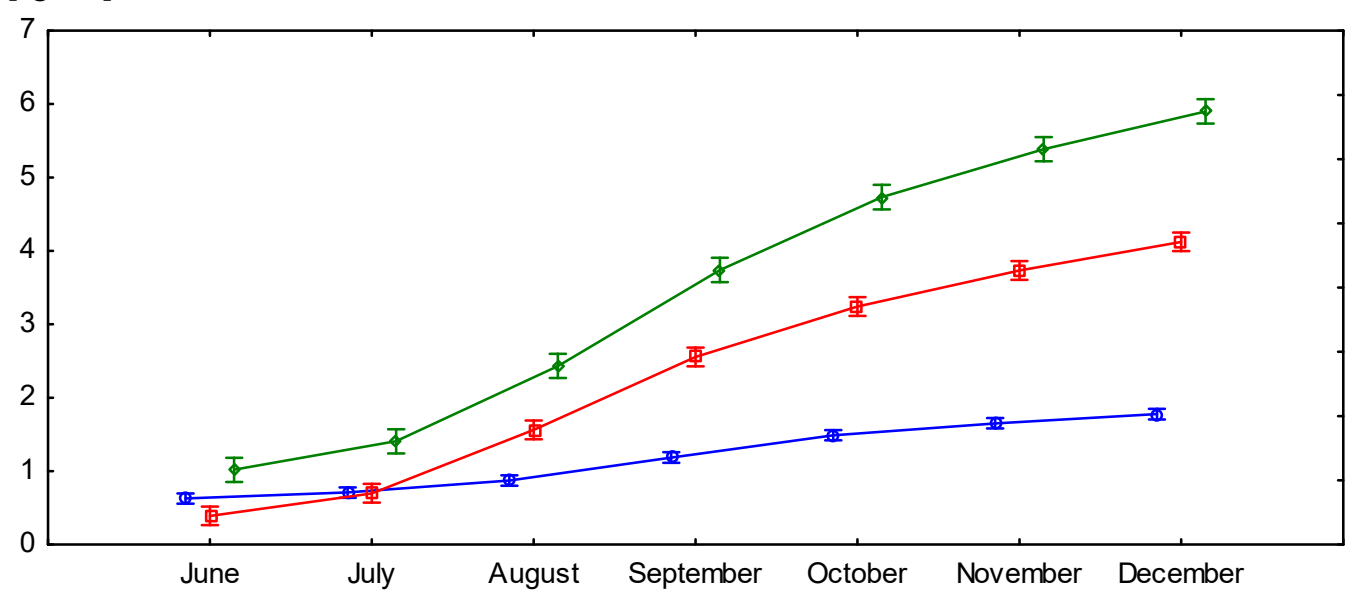

Standard error:

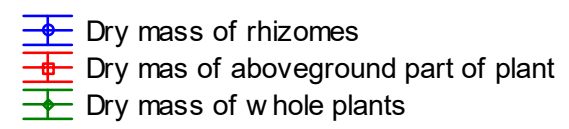

Figure 8. Dry mass yield of the rhizomes and the aboveground part of the plant during the vegetation period of the years 2014-2016 (average for years).

The dry mass of aboveground parts of plants $(p=0.0153)$ and rhizomes $(p=0.0125)$ in 30-day intervals significantly differentiated from June to November, in which we obtained the highest values in December (Table 6, Figure 8). In July, the dry matter of leaves was slightly greater than that of the stems, and from this month the increase in the dry matter of stems was greater than that of the leaves. The period between June and July and the November and December vegetation days, constituted $29 \%$ 
of the entire vegetation period. During this time, a more than $18 \%$ increase in the dry weight of the rhizomes and aboveground parts was observed.

\subsection{Nitrogen Uptake by Miscanthus $\times$ Giganteus}

Nitrogen fertilization caused a significant increase in the nitrogen uptake in all the examined parts of plants $(p=0.0000)$. For the control object, the nitrogen uptake by rhizomes decreased until July, whereas in fertilized plots it decreased until August $(p=0.0118)$ (Table 7). The highest uptake of nitrogen in rhizomes was found in December, while in whole plants it was found in November. Therefore, it can be presumed that rhizomes can be a nitrogen reserve for shoots. In the initial vegetation period, the nitrogen uptake in leaves was higher than that in stems. The accumulation of nitrogen in stems was found to be higher than in leaves starting in August (Figure 9). The highest nitrogen uptake was found in the case of whole plants, with an increasing tendency from July to September, where the differences became insignificant (Figure 10). The fastest increase in the $\mathrm{N}$ uptake by rhizomes was observed from October to November (Figure 10). In the case of the aboveground parts of plants, the nitrogen uptake increased from June to September and then decreased (Figure 10).

Table 7. Nitrogen uptake of Miscanthus $\times$ giganteus $\left(\mathrm{kg} \mathrm{m}^{-2}\right)$ (average for years 2014-2016).

\begin{tabular}{|c|c|c|c|c|c|c|}
\hline \multirow{2}{*}{$\begin{array}{c}\text { Dose } \\
\mathrm{kg} \mathrm{ha}^{-1} \mathrm{~N}\end{array}$} & \multirow{2}{*}{$\begin{array}{c}\text { Number of Days from } \\
\text { the Start of the } \\
\text { Growing Season }\end{array}$} & \multirow[t]{2}{*}{ Rhizomes } & \multicolumn{3}{|c|}{$\begin{array}{l}\text { Aboveground } \\
\text { Part of Plants }\end{array}$} & \multirow{2}{*}{$\begin{array}{l}\text { Rhizomes and } \\
\text { Aboveground } \\
\text { Part of Plants }\end{array}$} \\
\hline & & & Stems & Leaves & Together & \\
\hline \multirow{7}{*}{0} & June & 5.35 & - & - & 4.75 & 10.10 \\
\hline & July & 3.25 & 3.16 & 4.34 & 7.50 & 10.75 \\
\hline & August & 3.65 & 8.24 & 4.79 & 13.03 & 16.68 \\
\hline & September & 5.29 & 10.24 & 5.99 & 16.24 & 21.53 \\
\hline & October & 6.62 & 8.50 & 6.04 & 14.54 & 21.16 \\
\hline & November & 10.19 & 8.61 & 6.66 & 15.27 & 25.46 \\
\hline & December & 10.68 & 7.97 & 3.97 & 11.95 & 22.63 \\
\hline \multirow{7}{*}{60} & June & 9.24 & - & - & 7.60 & 16.84 \\
\hline & July & 5.79 & 5.08 & 6.98 & 12.05 & 17.84 \\
\hline & August & 5.40 & 8.63 & 9.52 & 18.15 & 23.55 \\
\hline & September & 6.91 & 14.36 & 11.01 & 25.37 & 32.28 \\
\hline & October & 7.72 & 15.71 & 8.78 & 24.51 & 32.23 \\
\hline & November & 14.07 & 12.82 & 7.19 & 20.01 & 34.08 \\
\hline & December & 14.94 & 12.40 & 5.74 & 18.15 & 33.09 \\
\hline \multicolumn{2}{|r|}{$p$ value } & 0.0118 & 0.0000 & 0.000 & 0.0000 & 0.0000 \\
\hline \multicolumn{7}{|c|}{ Means for Factors and Years } \\
\hline 0 & & 6.43 & 7.79 & 5.30 & 11.90 & 18.33 \\
\hline 60 & & 9.15 & 11.50 & 8.20 & 17.98 & 27.13 \\
\hline & $p$ value & 0.0000 & 0.0000 & 0.0000 & 0.0000 & 0.0000 \\
\hline & 2014 & 8.18 & 10.07 & 6.53 & 15.06 & 23.24 \\
\hline & 2015 & 7.48 & 10.10 & 7.05 & 15.55 & 23.03 \\
\hline & 2016 & 7.71 & 8.77 & 6.67 & 14.19 & 21.89 \\
\hline & $p$ value & 0.6315 & 0.1925 & 0.5895 & 0.5205 & 0.6493 \\
\hline
\end{tabular}




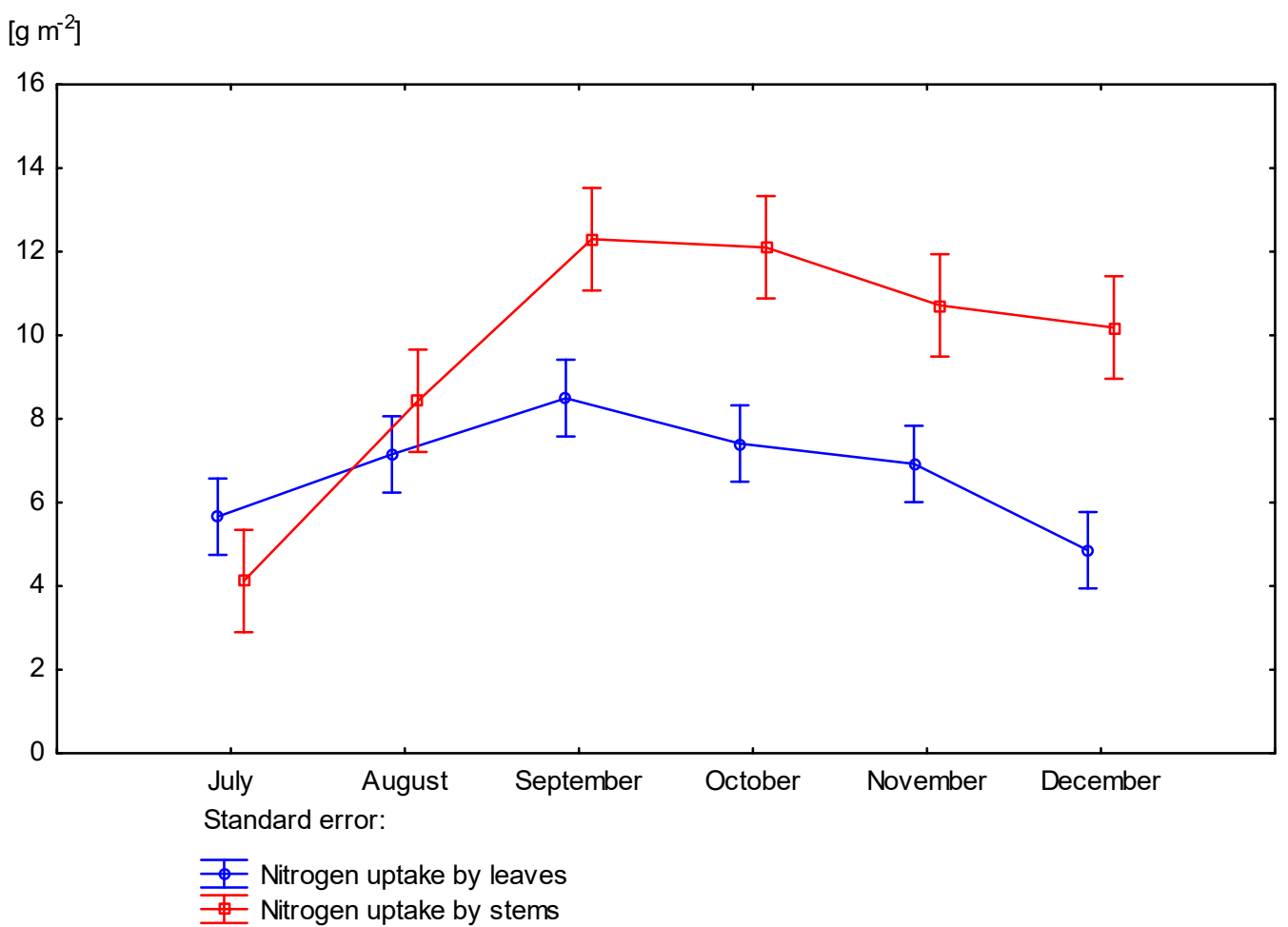

Figure 9. Nitrogen uptake by leaves and stems during the vegetation period in the years 2014-2016 (average for years).

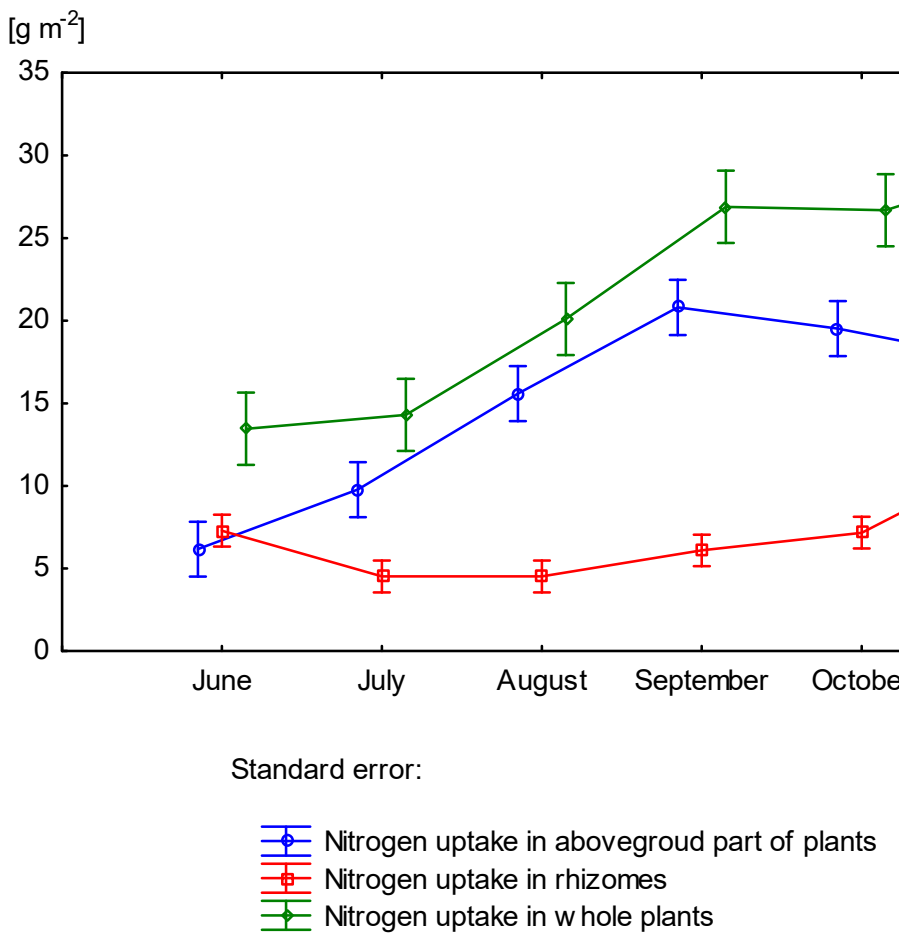

Figure 10. Nitrogen uptake by the whole plants (average for years).

\section{Discussion}

Nitrogen fertilization is important for biomass production and its components. The results provided statistical evidence to prove that the number of shoots responded positively to $\mathrm{N}$ fertilization. Other studies have also shown an increase in the number of shoots after applying N [53-55]. The water 
concentration in rhizomes and stems, the yield of dry mass leaves, and the nitrogen uptake was dependent on the level of nitrogen fertilization. Higher water content promoted metabolic processes and faster dry mass accumulation [56]. Therefore, research has been undertaken to determine the influence of nitrogen fertilization on the dynamics of the water content changes in rhizomes during the whole vegetation period. According to Drazic et al. (2017) [25], the number of stems per rhizome depended strongly on the soil type and was in strong positive correlation with the yield in all years. In our own research, the number of shoots were not significantly different during the experimental years.

In our research, the application of nitrogen stimulated the number of shoots. The plant height was also increased by $\mathrm{N}$ fertilization in various terms of harvesting. The plant height increased after the application of N, which was also reported by Cosentino et al. (2007) [54] and Finnan and Burke (2014) [39].

There have been conflicting results concerning the yield response of Miscanthus $\times$ giganteus to nitrogen fertilization and its yield components. Our positive responses to nitrogen fertilization were in agreement with Arundale et al. 2014 [57]. Moreover, Greef, J.M. (1995) [35] and Lee and Boe (2005) [26] obtained similar results when applying a $60 \mathrm{~kg} \mathrm{ha}^{-1} \mathrm{~N}$ dose as appropriate for proper rhizome development and Miscanthus $\times$ giganteus yield increase. In the research of Dierking et al. (2017) [17], a dose of $75 \mathrm{~kg} \mathrm{ha}^{-1} \mathrm{~N}$ contributed to the increase in the Miscanthus biomass yield, and this amount was applied annually. In the research of Lee and Boe (2005) [26], the dry matter yield visibly increased when the nitrogen fertilization increased up to $60 \mathrm{~kg} \mathrm{ha}^{-1} \mathrm{~N}$. However, increasing the nitrogen dose further did not contribute to an increase in the Miscanthus yields. The Miscanthus dry matter yields obtained in this research were 2.55 and $2.49 \mathrm{~kg} \mathrm{~m}^{-2}$ for 60 and $120 \mathrm{~kg} \mathrm{ha}^{-1} \mathrm{~N}$, while in the control plant it was $1.3 \mathrm{~kg} \mathrm{~m}^{-2}$. Schwarz et al., 1994 [34], conducted an experiment involving nitrogen fertilization that did not have a significant impact on the Miscanthus yield. In their second year of cultivation, they obtained a yield of $0.8 \mathrm{~kg} \mathrm{~m}^{-2}$, and in the third year they obtained $2.2 \mathrm{~kg} \mathrm{~m}^{-2}$. Moreover, many other studies have shown that nitrogen fertilization is not required to obtain high yields of Miscanthus $\times$ giganteus biomass [58]. Christian et al. (2008) [33] did not find any answer to the applied $\mathrm{N}$ in 14 consecutive harvests. This result is supported by other studies that showed no response to $\mathrm{N}$ fertilization. However, some experiments have been concerned with soils featuring a large $\mathrm{N}$ content $[13,21,25,34]$. No reaction to nitrogen was found during the first two years after planting. Maughan et al. 2012 [21] reported a small positive reaction in a dose of $100 \mathrm{~kg} \mathrm{ha}^{-1} \mathrm{~N}$ of fertilizer. According to Kering et al. (2012) [13], Himken et al. (1997) [58], and Miquez et al. (2008) [21], Miscanthus yields are not dependent on the level of nitrogen fertilization, as they determined $2.5-3.0 \mathrm{~kg} \mathrm{~m}^{-2}$ of D.M. and even $3.8 \mathrm{~kg} \mathrm{~m}^{-2}$ of D.M. In our research, the dry matter yield with the nitrogen fertilization of all examined plants was insignificantly higher compared to the control. Only the leaf yields of D.M. depended on nitrogen fertilization.

The ambiguous response to nitrogen fertilization results from several reasons:

1. Most research on Miscanthus productivity has been conducted in Europe (different soils, different spatial diversity, and topographic diversity);

2. The studies carried out are generally short-term;

3. The soil type and soil texture $[21,37,59]$;

4. The potential share of nitrogen reserves in rhizomes and soil nitrogen increases the uncertainty of the Miscanthus nitrogen requirements [29].

Precipitation is the most important factor that directly and indirectly affects the biomass yield of Miscanthus $\times$ giganteus. Plant biomass production reacts positively to annual rainfall [60], and the seasonal distribution of rainfall is a key factor that determines the formation of perennial grasses and biomass yield [26,60]. In this experiment, the precipitation was variable during the 3-year study period, with much less precipitation than 2015. In our research, the most favorable year with a high and evenly distributed precipitation was in 2016; however, this did not translate into dry matter yields but rather 
translated to the water content in all the examined plant parts. According to Heaton et al. (2004) [46], the biomass yield may be affected by rainfall during the growing season from April to September.

The nitrogen uptake was significantly affected by the analyzed factors-nitrogen fertilization and the term of harvesting. According to Roncucci et al. (2014) [14], the time of harvest is the most relevant factor in influencing the miscanthus nutrient uptakes. Late harvesting $(\mathrm{W})$ led to a reduction in the nitrogen uptake of about $80 \%$ in the aboveground biomass. This nitrogen uptake is observed to be lower than the literature data. In 10 years of research in the UK, Christian et al. (2008) [33] reported that the $\mathrm{N}$ is 76 and $6 \mathrm{~kg} \mathrm{ha}^{-1} \mathrm{~N}$. According to Roncucci et al. (2014) [14], $\mathrm{N}$ fertilization affected the nutrient uptake mainly in autumn, with no differences in winter. These results are in agreement with those of Himken et al. (1997) [58], who observed a higher $N$ uptake with higher $\mathrm{N}$ fertilization rates in November, which is confirmed by our results. Nitrogen fertilization in the fertilizer treatments significantly affected the nitrogen uptake by all plant parts, which is confirmed by Strullu et al. (2011) [30].

Slightly higher results relating to the nitrogen uptake under various $\mathrm{N}$ doses in the harvest biomass of giant miscanthus were found in Christian et al. (2008) [33]. In Beale et al. (1997) [29], the rhizome nitrogen uptake decreased until July and then increased until December. Similar conclusions were presented in our research.

\section{Conclusions}

Nitrogen fertilization did not contribute to the increase in all the examined yield components. The proposed dose caused an increase in all the components of features and the dry matter yield. However, the differences were mostly insignificant. Only the dry mass of leaves increased significantly in the experiment. The water content in the rhizomes and stems increased under nitrogen fertilization. Therefore, we can assume that rhizomes, because of their significant nitrogen uptake, can constitute a nitrogen reserve for elements in the initial growth and development stages of plants. The results coming from our 3-year field experiment suggest that $\mathrm{N}$ fertilization is unnecessary for sustainable biomass production.

Author Contributions: Conceptualization, I.G.-B., W.H., and A.K.; data curation, M.K.; formal analysis, W.H. and A.J.-R.; investigation, I.G.-B., W.H., and M.K.; methodology, I.G.-B. and A.K.; project administration, I.G.-B.; resources, A.K. and A.J.-R.; software, M.K.; supervision, M.K.; visualization, M.K. and A.J.-R.; writing-original draft, I.G.-B. and W.H.; writing-review and editing, A.K. and A.J.-R. All authors have read and agreed to the published version of the manuscript.

Funding: This research received no external funding.

Conflicts of Interest: The authors declare no conflict of interest. The funders had no role in the design of the study; in the collection, analysis, or interpretation of data; in the writing of the manuscript; or in the decision to publish the results.

\section{References}

1. Baxter, X.C.; Darvell, L.I.; Jones, J.M.; Barraclough, T.; Yates, N.E.; Shield, I. Miscanthus combustion properties and variations with Miscanthus agronomy. Fuel 2014, 117, 851-869. [CrossRef]

2. Karl, T.R.; Trenberth, K.E. Modern global climate change. Science 2003, 302, 1719-1723. [CrossRef] [PubMed]

3. Easterling, D.R.; Meehl, G.A.; Parmesan, C.; Changnon, S.A.; Karl, T.R.; Mearns, L.O. Climate extremes: Observations, modeling, and impacts. Science 2000, 289, 2068-2074. [CrossRef] [PubMed]

4. Capellán-Pérez, I.; Mediavilla, M.; de Castro, C.; Carpintero, Ó.; Miguel, L.J. Fossil fuel depletion and socio-economic scenarios: An integrated approach. Energy 2014, 77, 641-666.

5. Shafiee, S.; Topal, E. When will fossil fuel reserves be diminished? Energy Policy 2009, 37, 181-189. [CrossRef]

6. Hager, H.A.; Sinasac, S.E.; Gedalof, Z.; Newman, J.A. Predicting potential global distributions of two miscanthus grasses: Implications for horticulture, biofuel production, and biological invasions. PLOS ONE 2014, 9, e100032. [CrossRef]

7. Hastings, A.; Clifton-brown, J.; Wattenbach, M.; Mitchell, C.P.; Stampfl, P.; Smith, P. Future energy potential of Miscanthus in Europe. GCB Bioenergy 2009, 30, 1058. [CrossRef] 
8. Lewandowski, I.; Clifton-Brown, J.; Trindade, L.M.; Van Der Linden, G.C.; Schwarz, K.U.; Müller-Sämann, K.; Anisimov, A.; Chen, C.L.; Dolstra, O.; Donnison, I.S.; et al. Progress on optimizing miscanthus biomass production for the european bioeconomy: Results of the EU FP7 Project OPTIMISC. Front. Plant Sci. 2016, 7, 1620. [CrossRef]

9. Lewandowski, I.; Clifton-Brown, J.; Scurlock, J.; Huisman, W. Miscanthus: European experience with a novel energy crop. Biomass Bioenergy 2000, 19, 209-227. [CrossRef]

10. Von Cossel, M.; Lewandowski, I.; Elbersen, B.; Staritsky, I.; Van Eupen, M.; Iqbal, Y.; Mantel, S.; Scordia, D.; Testa, G.; Cosentino, S.L.; et al. Marginal agricultural land low-input systems for biomass production. Energies 2019, 12, 3123. [CrossRef]

11. Jenkins, B.; Baxter, L.; Miles, T. Combustion properties of biomass. Fuel Process. Technol. 1998, 54, 17-46. [CrossRef]

12. Sahoo, K.; Milewski, A.; Mani, S.; Hoghooghi, N.; Panda, S. Assessment of miscanthus yield potential from strip-mined lands (SML) and its impacts on stream water quality. Water 2019, 11, 546. [CrossRef]

13. Kering, M.K.; Butler, T.J.; Biermacher, J.T.; Guretzky, J.A. Biomass yield and nutrient removal rates of perennial grasses under nitrogen fertilization. BioEnergy Res. 2011, 5, 61-70. [CrossRef]

14. Roncucci, N.; Di Nasso, N.N.O.; Tozzini, C.; Bonari, E.; Ragaglini, G. Miscanthus $\times$ giganteus nutrient concentrations and uptakes in autumn and winter harvests as influenced by soil texture, irrigation and nitrogen fertilization in the Mediterranean. GCB Bioenergy 2015, 7, 1009-1018. [CrossRef]

15. Heaton, E.A.; Dohleman, F.G.; Long, S.P. Meeting US biofuel goals with less land: The potential of Miscanthus. Glob. Chang. Biol. 2008, 14, 2000-2014. [CrossRef]

16. Heaton, E.A.; Dohleman, F.G.; Miguez, A.F.; Juvik, J.A.; Lozovaya, V.; Widholm, J.; Zabotina, O.A.; McIsaac, G.F.; David, M.B.; Voigt, T.B.; et al. Miscanthus. A promising biomass crop. Adv. Bot. Res. 2010, 56, 75-137. [CrossRef]

17. Dierking, R.M.; Allen, D.J.; Cunningham, S.M.; Brouder, S.M.; Volenec, J.J. Nitrogen reserve pools in two Miscanthus $\times$ giganteus genotypes under contrasting $N$ managements. Front. Plant Sci. 2017, 8, 1618. [CrossRef]

18. Stavridou, E.; Hastings, A.; Webster, R.; Robson, P. The impact of soil salinity on the yield, composition and physiology of the bioenergy grass Miscanthus $\times$ giganteus. GCB Bioenergy 2017, 9, 92-104. [CrossRef]

19. Stefanovska, T.; Pidlisnyuk, V.; Lewis, E.; Gorbatenko, A. Herbivorous insects diversity at miscanthus $\times$ giganteus in Ukraine. Agriculture 2017, 63, 23-32. [CrossRef]

20. Galatsidas, S.; Gounaris, N.; Vlachaki, D.; Dimitriadis, E.; Kiourtsis, F.; Keramitzis, D.; Gerwin, W.; Repmann, F.; Rettenmaier, N.; Reinhardt, G.; et al. Revealing bioenergy potentials: Mapping marginal lands in Europe-The seemla approach. In Proceedings of the European Biomass Conference and Exhibition, Copenhagen, Denmark, 14-17 May 2018.

21. Maughan, M.; Bollero, G.; Lee, D.K.; Darmody, R.; Bonos, S.; Cortese, L.; Murphy, J.; Gaussoin, R.; Sousek, M.; Williams, D.; et al. Miscanthus $\times$ giganteus productivity: The effects of management in different environments. GCB Bioenergy 2012, 4, 253-265. [CrossRef]

22. Zub, H.W.; Brancourt-Hulmel, M. Agronomic and physiological performances of different species ofMiscanthus, a major energy crop. A review. Agron. Sustain. Dev. 2010, 30, 201-214. [CrossRef]

23. Styles, D.; Jones, M.B. Energy crops in Ireland: Quantifying the potential life-cycle greenhouse gas reductions of energy-crop electricity. Biomass Bioenergy 2007, 31, 759-772. [CrossRef]

24. Di Nasso, N.N.O.; Roncucci, N.; Triana, F.; Tozzini, C.; Bonari, E. Seasonal nutrient dynamics and biomass quality of giant reed (Arundo donax L.) and miscanthus (Miscanthus $\times$ giganteus Greef et Deuter) as energy crops. Ital. J. Agron. 2011, 6, 152-158. [CrossRef]

25. Drazic, G.; Milovanovic, J.; Stefanovic, S.; Petric, I. Potential of Miscanthus $\times$ Giganteus for heavy metals removing from industrial deposol. Acta Reg. Environ. 2017, 2, 56-58.

26. Lee, D.K.; Boe, A. Biomass production of switchgrass in central south Dakota. Crop. Sci. 2005, 45, 2583. [CrossRef]

27. Dohleman, F.G.; Heaton, E.A.; Arundale, R.A.; Long, S.P. Seasonal dynamics of above- and below-ground biomass and nitrogen partitioning in Miscanthus $\times$ giganteus and Panicum virgatum across three growing seasons. GCB Bioenergy 2012, 4, 534-544. [CrossRef]

28. Clifton-Brown, J.C.; Lewandowski, I. Water use efficiency and biomass partitioning of three different miscanthus genotypes with limited and unlimited water supply. Ann. Bot. 2000, 86, 191-200. [CrossRef] 
29. Beale, C.; Long, S. Seasonal dynamics of nutrient accumulation and partitioning in the perennial C4-grasses Miscanthus $\times$ giganteus and Spartina cynosuroides. Biomass Bioenergy 1997, 12, 419-428. [CrossRef]

30. Strullu, L.; Cadoux, S.; Preudhomme, M.; Jeuffroy, M.H.; Beaudoin, N. Biomass production and nitrogen accumulation and remobilisation by Miscanthus $\times$ giganteus as influenced by nitrogen stocks in belowground organs. Field Crop. Res. 2011, 121, 381-391. [CrossRef]

31. Cadoux, S.; Riche, A.B.; Yates, N.E.; Machet,J.M. Nutrient requirements of Miscanthus $\times$ giganteus: Conclusions from a review of published studies. Biomass Bioenergy 2012, 38, 14-22. [CrossRef]

32. Arundale, R.A.; Dohleman, F.G.; Heaton, E.A.; McGrath, J.M.; Voigt, T.B.; Long, S.P. Yields of Miscanthus $\times$ giganteus and panicum virgatum decline with stand age in the Midwestern USA. GCB Bioenergy 2014, 6 , 71-87. [CrossRef]

33. Christian, D.; Riche, A.; Yates, N. Growth, yield and mineral content of Miscanthus $\times$ giganteus grown as a biofuel for 14 successive harvests. Ind. Crop. Prod. 2008, 28, 320-327. [CrossRef]

34. Schwarz, H.; Liebhard, P.; Ehrendorfer, K.; Ruckenbauer, P. The effect of fertilization on yield and quality of Miscanthus sinensis 'Giganteus'. Ind. Crop. Prod. 1994, 2, 153-159. [CrossRef]

35. Greef, J.M. Etablierung und Biomassebildung von Miscanthus $\times$ Giganteus; Cuvillier Verlag: Gottingen, Germany, 1995; pp. 1-162.

36. Kahle, P.; Beuch, S.; Boelcke, B.; Leinweber, P.; Schulten, H.R. Cropping of Miscanthus in Central Europe: Biomass production and influence on nutrients and soil organic matter. Eur. J. Agron. 2001, 15, 171-184. [CrossRef]

37. Lee, M.-S.; Wycislo, A.; Guo, J.; Lee, D.K.; Voigt, T. Nitrogen fertilization effects on biomass production and yield components of Miscanthus $\times$ giganteus. Front. Plant Sci. 2017, 8, 1-9. [CrossRef]

38. Yost, M.A.; Randall, B.K.; Kitchen, N.R.; Heaton, E.A.; Myers, R.L. Yield potential and nitrogen requirements of miscanthus $\times$ giganteus on eroded soil. Agron. J. 2017, 109, 684-695. [CrossRef]

39. Finnan, J.; Burke, B. Nitrogen dynamics in a mature Miscanthus $\times$ giganteus crop fertilized with nitrogen over a five year period. Irish J. Agric. Food Res. 2014, 53, 171-188.

40. Wildová, R.; Wild, J.; Herben, T. Fine-scale dynamics of rhizomes in a grassland community. Ecography 2007, 30, 264-276. [CrossRef]

41. Mann, J.J.; Barney, J.N.; Kyser, G.B.; DiTOMASO, J.M. Root system dynamics of Miscanthus $\times$ giganteus and panicum virgatum in response to rainfed and irrigated conditions in California. BioEnergy Res. 2013, 6, 678-687. [CrossRef]

42. Ameen, A.; Liu, J.; Han, L.P.; Xie, G.H. Effects of nitrogen rate and harvest time on biomass yield and nutrient cycling of switchgrass and soil nitrogen balance in a semiarid sandy wasteland. Ind. Crop. Prod. 2019, 136, 1-10. [CrossRef]

43. Peixoto, M.; Friesen, P.C.; Sage, R.F. Winter cold-tolerance thresholds in field-grown Miscanthus hybrid rhizomes. J. Exp. Bot. 2015, 66, 4415-4425. [CrossRef]

44. Clifton-Brown, J.C.; Lewandowski, I. Overwintering problems of newly established Miscanthus plantations can be overcome by identifying genotypes with improved rhizome cold tolerance. New Phytol. 2000, 148, 287-294. [CrossRef]

45. Ahmadi, S.H.; Agharezaee, M.; Kamgar-Haghighi, A.A.; Sepaskhah, A.R. Comparing canopy temperature and leaf water potential as irrigation scheduling criteria of potato in water-saving irrigation strategies. Int. J. Plant Prod. 2017, 11, 333-347.

46. Heaton, E. A quantitative review comparing the yields of two candidate $\mathrm{C} 4$ perennial biomass crops in relation to nitrogen, temperature and water. Biomass Bioenergy 2004, 27, 21-30. [CrossRef]

47. IUNG-PIB. Available online: http://www.iung.pulawy.pl/ (accessed on 13 September 2020).

48. Avramidis, P.; Nikolaou, K.; Bekiari, V. Total organic carbon and total nitrogen in sediments and soils: A comparison of the wet oxidation-Titration method with the combustion-infrared method. Agric. Agric. Sci. Procedia 2015, 4, 425-430. [CrossRef]

49. Kondratowicz-Maciejewska, K.; Kobierski, M. Content of available magnesium, phosphorus and potassium forms in soil exposed to varied crop rotation and fertilisation. J. Elementology 2011, 16, 543-553. [CrossRef]

50. Slepetiene, A.; Slepetys, J. Status of humus in soil under various long-term tillage systems. Geoderma 2005, 127, 207-215. [CrossRef]

51. Kilmer, V.J.; Nearpass, D.C. The determination of available sulfur in soils. Soil Sci. Soc. Am. J. 1960, 24, 337-340. [CrossRef] 
52. De Rooij, G.H. Methods of soil analysis. Vadose Zone J. 2004, 24, 337-340.

53. Finnan, J.; Burke, B. Nitrogen fertilization of Miscanthus $\times$ giganteus: Effects on nitrogen uptake, growth, yield and emissions from biomass combustion. Nutr. Cycl. Agroecosyst. 2016, 106, 249-256. [CrossRef]

54. Cosentino, S.; Patanè, C.; Sanzone, E.; Copani, V.; Foti, S. Effects of soil water content and nitrogen supply on the productivity of Miscanthus $\times$ giganteus Greef et Deu. in a Mediterranean environment. Ind. Crop. Prod. 2007, 25, 75-88. [CrossRef]

55. Wiesler, F.; Dickmann, J.; Horst, W.J. Effects of nitrogen supply on growth and nitrogen uptake byMiscanthus sinensis during establishment. J. Plant Nutr. Soil Sci. 1997, 160, 25-31. [CrossRef]

56. Chen, Z.; Tao, X.; Khan, A.; Tan, D.K.Y.; Luo, H. Biomass Accumulation, photosynthetic traits and root development of cotton as affected by irrigation and nitrogen-fertilization. Front. Plant Sci. 2018, 9, 1-14. [CrossRef] [PubMed]

57. Anderson, E.; Arundale, R.; Maughan, M.; Oladeinde, A.; Wycislo, A.; Voigt, T. Growth and agronomy of Miscanthus $\times$ giganteus for biomass production. Biofuels 2011, 2, 71-87. [CrossRef]

58. Himken, M.; Lammel, J.; Neukirchen, D.; Czypionka-Krause, U.; Olfs, H.W. Cultivation of Miscanthus under West European conditions: Seasonal changes in dry matter production, nutrient uptake and remobilization. Plant Soil 1997, 189, 117-126. [CrossRef]

59. Miguez, F.E.; Villamil, M.; Long, S.P.; Bollero, G.A. Meta-analysis of the effects of management factors on Miscanthus×giganteus growth and biomass production. Agric. For. Meteorol. 2008, 148, 1280-1292. [CrossRef]

60. Paruelo, J.; Lauenroth, W.K.; Burke, I.C.; Sala, O.E. Grassland precipitation-use efficiency varies across a resource gradient. Ecosystems 1999, 2, 64-68. [CrossRef]

(C) 2020 by the authors. Licensee MDPI, Basel, Switzerland. This article is an open access article distributed under the terms and conditions of the Creative Commons Attribution (CC BY) license (http://creativecommons.org/licenses/by/4.0/). 